\title{
化学自组装之路: 我们能够走多远?
}

\author{
黎占亭 \\ 复旦大学化学系, 上海 200433 \\ E-mail: ztli@fudan.edu.cn \\ 2016-07-17 收稿, 2016-08-08 修回, 2016-08-10 接受, 2016-08-16 网络版发表 \\ 国家自然科学基金(21432004, 91527301)和国家重点基础研究发展计划(2013CB834501)资助
}

\begin{abstract}
摘要生命是自然界化学自组装的完美体现和最高境界. 生物自组装是化学自组装研究结构设计及原理和功能 创新的源泉。本文对未来化学自组装研究在模拟生命体系的高等人工自组装体系构建、不同尺度的自组装生物、 能源和信息材料开发及新的自组装物种及多层次控制等方面做了展望.
\end{abstract}

关键词自组装, 生物模拟, 功能性自组装体系, 生物医用材料, 光电材料

生命是自然界化学自组装(self-assembly)的完美 体现和最高境界. 蛋白质通过氢键, 疏水作用及静电 作用等形成螺旋、折叠和回转等二级结构, 多个二级 结构域发生分子内簇集形成三级结构, 三级结构再 进一步通过分子间选择性结合形成四级结构, 从而 通过多级次自组装形成各种复杂功能体. 核酸则通 过编码式的碱基对氢键和堆积形成双螺旋等结构, 从而完成遗传之使命. 生物分子自组装的另一个典 型例子是两亲性的磷脂受疏水作用驱动形成双层膜, 形成细胞这一生命的基本单元. 低级生物可以是单 个细胞, 而高等生物则需要由细胞到组织、到器官、 再到生命体的更高级组装. 生物分子自组装的特征 是分子和大分子单体具有高度的结构多样性和复杂 性, 从而能够实现组装体高度的结构复杂性和功能 多样性, 组装过程也具有高度的可逆性, 纠错及自修 复性和外界刺激响应性等. 因此, 生物自组装是化学 自组装研究结构设计及原理和功能创新的源泉.

化学自组装研究最早开始于在金表面组装单分 子层膜, 是更早期分子识别和超分子化学研究在理 念和目标上重要的扩展. 近30年来, 自组装的概念在 化学、生物和材料科学领域的运用非常宽泛, 几乎达
到“一切皆为自组装”的程度. 但化学自组装典型意 义上是指分子或大分子受非共价作用力驱动自发可 逆形成分子聚集体的过程. 与化学自组装相关的一 个表达是化学自组织(self-organization). 诺贝尔化学 奖获得者Jean-Marie Lehn认为, 与得到广泛使用的 “自组装”概念不同, “自组织”不同于“自组装”, 除了 表达自发地形成聚集体外, “自组织”还表示形成聚集 体是一个“有组织”的过程 ${ }^{1]}$. 由于这两个概念的含义 文献中常常相互覆盖, 本文统一使用“自组装”论述 相应观点.

化学自组装在过去的三十多年已经取得了极大 地进展. 生命体中几乎所有的重要组装体形式, 如 DNA双螺旋结构、蛋白质二级及更高级结构、细胞 球形膜结构、分子马达及肌肉运动等, 都已经通过化 学自组装构造出人工的模拟体系，一些人工模拟体 系在一定程度上还可以展示生物组装体的特定功能. 例如, 一些人工酶在温和条件下就可以展示相当高 的催化功能. 化学自组装研究的另一方面主要进展 体现在化学家能够通过设计合成分子和大分子，构 造出自然界不存在的自组装结构. 如对互穿结构如 轮烷、索烃和分子结的研究已发展出许多功能奇特的

引用格式: 黎占亭. 化学自组装之路: 我们能够走多远? 科学通报, 2016, 61: 2872-2875

Li Z T. How far can we push chemical self-assembly? A personal interpretation (in Chinese). Chin Sci Bull, 2016, 61: 2872-2875, doi: 10.1360/N972016-00876 
分子器件. 许多自组装的分子胶囊能够通过包结控 制被包结分子和离子客体的物理和化学性质等. 通 过非共价键连接形成的超分子聚合物在自修复材料 及药物输送等研究领域展示出良好的应用前景.

2005年, Science在创刊125周年之际提出了 21 世 纪面临解决的 125 个最具挑战性的科学问题, “我们能 推动化学自组装走多远?”(How far can we push chemical self-assembly?)作为一个化学领域的重要科 学问题被推出 ${ }^{[2]}$. 十年来化学自组装研究持续不断发 展, 发表的论文逐年递增, 但很多关键科学问题仍尚 待解决. 预测一个重要的研究领域能走多远实际上 不可能, 也没有实际的意义. 因此, 本文试图抽提出 个人认为本领域一些共性的关键科学和技术问题和 应用发展的瓶颈. 这些科学和技术问题的解决将带 来本领域研究的新突破, 当然也会推动整个学科的 进一步发展.

自然界通过数十亿年进化出生命这一最高级自 组装形式. 化学家开展化学自组装研究, 一个最重要 的思想源泉即是师法自然. 这方面的研究有以下几 个目的. (1) 探索控制生物自组装的非共价键作用机 制和规律, 为利用和改造生物自组装体系, 发展新的 功能组装体系提供原理和灵感. (2) 探索分子和大分 子在纳米、微米、介观及宏观尺度上定向排列形成有 序组装体的非共价键方法. 科学家已经认识到, 组装 体内的分子组分和组装体整体可以表现出与单个孤 立的分子单元非常不同的理化、生物及材料性质. 但 实现大尺度的定向分子自组装, 尤其是在液相和表 界面, 仍然是一个挑战. (3) 化学研究走向复杂性的 固有需要. 复杂性是化学家对分子群体性结构与性 质实施控制的必然要求, 也是开发分子新功能与新 应用的重要途径. 但总体上讲, 化学家通过设计合成 分子开展自组装研究仅仅数十年. 因此, 从生物模拟 的视角看, 化学自组装的体系与被模拟的生命体相 比, 从结构复杂性与多层次性和功能效率与选择性 等方面都还处于初级和低级的阶段.

(i ) 自组装人工酶. 模拟酶的高效率和专一性 一直是化学家追求的一个重要目标. 目前化学模拟 酶的一个主要思路是设计分子和大分子主体, 把被 催化的底物通过非共价键作用力限定在催化位点附 近, 从而提高催化的效率. 但目前利用化学自组装体 系发展模拟酶催化的一个瓶颈是, 反应的产物分子 具有与反应底物类似、甚至于更强的与催化体系结合
的能力. 因此, 反应产物的积累降低甚至于毒化人工 酶催化体系. 如何克服这一难题仍需要从进一步研 究天然酶的结构-活性机制着手.

(ii ) 自我复制自组装体系与人工生命. DNA 的自我复制是生物模拟自组装化学研究的另一个重 要领域. 在过去的三十多年中, 化学家发展出了一些 简单的有机分子, 它们的反应产物可以作为模板选 择性络合底物分子, 从而加速底物的反应, 构成简单 的自我复制体系. 但是, 这一领域近年来进展缓慢. 一个瓶颈问题是目前设计的自我复制体系反应产生 的目标分子与作为模板的分子结合一般要比与底物 的结合更强. 在目标分子积累到一定浓度后会降低 模板效应即自我复制的能力. 自然界进化出了解螺 旋酶可以解开DNA的双螺旋结构. 解螺旋酶是必须 的吗? 如果是, 化学家能发展出非生物的解双股自 组装体系吗? 如果不是, 能存在自我复制过程中模 板效应优先的人工分子吗? 与之相关会产生几个化 学自组装研究的重要命题: 复制与遗传是否一定需 要非常复杂的大分子才能实现? 细胞、组织与器官的 分化能通过人工自组装体系实现吗? 可否通过合成 分子产生全人工的生命体系?

(iii) 人工光合作用. 光合作用是自然界的基本 反应, 叶绿体等通过形成高级自组装结构有效收集 太阳光能, 将水和二氧化碳转化为葡萄糖并放出氧 气, 再进一步转化为各种有机物. 发展自组装人工光 合作用体系, 实现利用太阳光的可持续产生清洁能 源新途径, 是化学家和材料科学家的梦想. 发展广义 的高效低廉的人工光合作用体系，不仅仅局限于二 氧化碳的化学转化与利用及光解水产生氢气和氧气. 人工固氮, 重要生物质的高附加值转化, 高消费量高 分子消费品的降解及再生资源利用, 稀有元素及重 金属离子的富集(环保与资源再生)等, 都是通过化学 自组装开展人工光合作用研究的重要命题. 通过设 计单个大分子或高分子也可以设计人工光合作用中 心, 但植物光合作用中心是典型的自组装结构, 通过 化学自组装途径应具有广阔的前景.

(iv) 跨膜主动输送. 跨膜输送是生命维持与代 谢的基础. 研究跨膜输送不仅科学意义重大, 而且与 疾病治疗和药物改造与增效密切相关. 跨膜输送有 被动和主动之分. 前者涉及从高浓度一侧向低浓度 一侧的运动, 目前发展的自组装输送体系都仅限于 被动输送. 主动输送是把离子或分子从低浓度一侧 
运输到高浓度一侧的逆浓度过程, 因此需要消耗能 量. 生物体有两种途径实现主动输送: 一是利用膜蛋 白通过消耗三磷酸腺苷(ATP)的化学能实现离子和生 物活性分子的主动输送, 被称为初级主动输送; 二是 利用膜两侧的电化学梯度, 通过输送蛋白介导, 不需 要消耗ATP实现逆浓度输送. 设计人工的输送分子 及超分子, 嵌人生物膜内实现跨膜主动输送, 理论上 应是可行的, 但这一领域少有探索 ${ }^{[3]}$.

化学自组装研究的一个非常重要的目的是发展 可用于服务人类社会的自组装体系. 组装体作为发 展高灵敏分析新技术的结构基础, 可以为服务人类 健康, 危险及爆炸品检测等提供新的检测手段. 目前 能源信息材料研制的一个瓶颈是分子材料的加工过 程缺乏足够的理论支持. 对自组装基本问题的持续 研究不但为新结构的构建提供新的思路, 还将可能 提供普适性原理, 使得材料研制从设计到加工能够 达到 “理性”的阶段. 所谓的材料基因组概念成功实 施的一个基本前提是对控制材料形成过程的自组装 原理和方法的深人研究. 在应用于药物改性与增效 方面, Doxil等目前已经上市的脂质体药物本质上是 典型的化学自组装体 ${ }^{[4]}$. 显然, 通过自组装的原理设 计新的药物控释产品, 未来将大有可为. 化学自组装 是一个软结构物质构建的过程, 其可逆性和自适应 性非常有利于自修复材料的开发. 目前已经有自组 装超分子自修复商品处于早期市场推广阶段 ${ }^{[5]}$. 考虑
到这类新材料的独特性能, 未来将具有更广阔的应 用前景.

化学的魅力在于可以设计合成自然界不存在的 分子, 从而为开发新的功能与应用提供物质结构基 础. 化学自组装提供了一个利用合成分子产生新物 质形态的基本重要手段, 新奇结构的构建将是自组 装长期研究的目标, 概念、理论和方法的创新将永无 止境. 通过组装新的结构, 可以不断发现新的科学现 象、性质和规律. 从组装的级次性来说, 实现分子在 微观、介观及宏观尺度上的可控排列将始终是化学家 努力的方向, 这一努力可以在二维和三维空间展 开 ${ }^{[1,6]}$, 并将可能成为制备二维和三维聚合物的最有 效手段 ${ }^{[7]}$, 成为合成化学技术的新突破. 生物分子和 生命在不同的尺度上可以表现出逐渐复杂和高级的 功能和行为. 因此, 可以预期, 合成分子组成的自组 装体系也可以表现出性能和行为尺度效应.一个大 胆的预测是, 化学家完全可以通过合成分子组装出 人工生命及类生命体, 它们甚至可以表现出一些自 然界生物体不具备的特征, 比如避免死亡及可以拆 卸等. 另外, 就生命起源而言 ${ }^{[8]}$, 是否存在一个共性 的“门槛”? 分子组装体复杂到什么程度, 才会产生 生命体的特征? 组成生命体的分子多样性需要达到 多大的程度, 才能够表现出生命的特征? 我们是否能 发展出单分子的生命等等? 对这些与生命相关的命 题, 通过化学自组装研究寻找答案是最合理的途径.

\section{参考文献}

1 Lehn J M. Perspectives in chemistry-Steps towards complex matter. Angew Chem Int Ed, 2013, 52: 2836-2850

2 Service R F. How far can we push chemical self-assembly? Science, 2005, 309: 95

3 Bennett I M, Farfano H M V, Bogani F, et al. Active transport of $\mathrm{Ca}^{2+}$ by an artificial photosynthetic membrane. Nature, 2002, 420: 398-401

4 Barenholz Y. Doxil ${ }^{\circledR}$ —The first FDA-approved nano-drug: Lessons learned. J Contr Release, 2012, 160: 117-134

5 van Gemert G M L, Peeters J W, Söntjens S H M, et al. Self-healing supramolecular polymers in action. Macromol Chem Phys, 2012, 213: 234-242

6 Tian J, Chen L, Zhang D W, et al. Supramolecular organic frameworks: Engineering periodicity in water through host-guest chemistry. Chem Commun, 2016, 52: 6351-6362

7 Payamyar P, King B T, Ottinger H C, et al. Two-dimensional polymers: Concepts and perspectives. Chem Commun, 2016, 52: 18-34

8 Küppers B O. Information and the Origin of Life. Cambridge: MIT Press, 1990 


\title{
How far can we push chemical self-assembly? A personal interpretation
}

\author{
LI Zhan-Ting \\ Department of Chemistry, Fudan University, Shanghai 200433, China
}

In the past fifty years we have witnessed great advance in the research field of chemical self-assembly. In the future, studies on chemical self-assembly will absolutely continue to be one of the most active research fields of chemical science. How far can we push chemical self-assembly in the coming decades? The answer is probably "no answer". But there are so many challenges which relate to chemical self-assembly and wait for chemists to address in the future. In my personal opinion, new advances or breakthroughs on tackling these challenges may be considered as the hallmarks where we have reached. Herein I would like to list some essential aspects concerning these challenges.

To some extent, life is the product of chemical self-assembly and represents its most advanced form. Thus, since its original stage, chemical self-assembly has largely borrowed the inspiration of life in assembling defined and functional structures. One important aspect for self-assembly research is the creation of so-called "artificial" systems that are able to mimic one or more essential behaviors or functions of life. We have already developed artificial enzymes, self-replication, photosynthetic systems and life, and so on by making use of self-assembly. However, we are not able to avoid enzyme poisoning, caused by increased binding of the products to their enzymes. DNA polymerase-like synthetic architectures are not available that would enable the catalysis of an artificial self-replication. Advance on photosynthesis research is still far away from practical application for producing clear energy. Even most advanced self-assembled architectures are only able to exhibit very simple characters relating to life. Clearly, there exists a huge space for the development of artificial self-assembled systems that mimic the behavior of life or biological species and eventually provide useful functions.

Self-assembly will strengthen its presence when it begins to produce more and more practical products for the human society. Currently, recognition-based devices have been used for public security, and several liposome drug products are also commercially available for improving drug treatment. However, applying self-assembly strategy to the development of new advanced materials is just at infancy stage. We may very much expect the generation of novel energy materials and smart self-healing materials in the future. In the context of molecular materials, the success of the so-called materials genome should, to a great extent, rely on the practicing of self-assembly principle for rational molecular design. With respect to fundamental research of self-assembly, we may say that the prospect is beyond imagination, from theory to structure. The ultimate vision may be the achievement of controllable operation on molecular arrangement from the nano scale to the micro-, meso-, and macroscale.

self-assembly, biomimetics, artificial functional species, biomedical material, photoelectric material

doi: 10.1360/N972016-00876

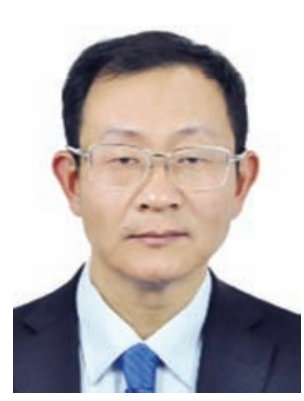

\section{黎占亭}

1985 年毕业于郑州大学化学系, 1992 年在中国科学院上海有机化学研究所获 博士学位, 曾在 University of South Denmark 和美国 University of Illinois at Urbana-Champaign 做博士后研究. 入选中国科学院“百人计划”并获国家杰出 青年科学基金资助, 现为复旦大学化学系教授. 长期开展自组装、分子识别 及生物结构模拟研究, 发表论文 220 余篇. 2013 年以来与赵新及刘毅等合作, 提出建立均相超分子有机框架(Supramolecular Organic Frameworks, SOFs) 自 组装结构体系。 